\title{
Political consciousness and the likelihood of workers from a sanitation company to politically engage in anti-privatization actions in southeastern Brazil
}

\author{
ESTÉFANES SILVA OLIVEIRA ${ }^{1}$ \\ MARCIA PREZOTTI PALASSI ${ }^{2}$ \\ Ana Paula Paes de Paula ${ }^{3}$
}

\author{
${ }^{1}$ AutONOMOUS ReSEARCHER, CARIACICA - ES, BRAZIL \\ ${ }^{2}$ Universidade Federal do Espírito Santo (UFES) / Administration Department, AdMinistration Post-Graduation Program,
} VITÓRIA - ES, BRAZIL

${ }^{3}$ Universidade Federal de Minas Gerais (UFMG) / Administrative SCIEnces Department, Post-Graduation ANd ReSEARCH CEnTER in AdMinistration, BElo HORIZONTE - MG, BRAZIL

\begin{abstract}
This article analyzes how political consciousness affects the likelihood of workers in a Brazilian sanitation company to engage in anti-privatization activities put forward by a union, seeking to understand the psychopolitical aspects of workers' participation in such movements. The research is based on studies of political psychology and uses the analytical model of political consciousness to understand participation in collective actions (Sandoval, 2001; Sandoval \& Silva, 2016). Data were obtained through an online questionnaire on the union's website, completed by 87 workers from different professional categories, out of a total of 1,400 company employees, submitted to content analysis. The results reveal political consciousness that are devoid of collective engagement, whose settings, according to professional categories, are: devoted employee- operational assistant; competitive employee-administrative assistant; diffuse worker-sanitation technicians, and expert worker-sanitation analyst. It is concluded that the feeling of opposition to the company's privatization predominates, but without workers' engagement in collective anti-privatization actions, opting for an individualistic attitude of preserving the position in the labor market. This research fills a gap in organizational studies with a psychopolitical approach to workers' (de)mobilization in privatization processes.
\end{abstract}

Keywords: Political Consciousness. Participation. Privatization. Organizational Studies. Public administration.

\section{Consciência política e predisposição à participação dos trabalhadores de uma empresa de saneamento em} ações coletivas contra a privatização no Sudeste do Brasil

\section{Resumo}

Este artigo analisa como a consciência política dos funcionários de uma empresa de saneamento, no Brasil, gera uma predisposição desses trabalhadores a favor ou contra o movimento sindical antiprivatização da empresa. O estudo visou a compreender os aspectos psicopolíticos da participação dos trabalhadores em ações coletivas antiprivatização conduzidas por uma organização sindical. A pesquisa se fundamenta em estudos da psicologia política e utiliza o modelo analítico de consciência política para compreensão da participação em ações coletivas (Sandoval, 2001; Sandoval \& Silva, 2016). Os dados foram obtidos por meio de um questionário on-line no site do sindicato, preenchido por 87 trabalhadores de diferentes categorias profissionais de um total de 1.400 funcionários da empresa, submetido a análise de conteúdo. Os resultados revelam consciências políticas desprovidas de engajamento coletivo, cujas configurações, conforme as categorias profissionais, são: a) trabalhador devoto - assistente operacional; b) trabalhador competitivo - assistente administrativo; c) trabalhador difuso - técnicos de saneamento; e d) trabalhador expert - analista em saneamento. Conclui-se que predomina o sentimento de oposição à privatização da empresa, porém, sem engajamento dos trabalhadores nas ações coletivas antiprivatização, optando por ações individuais voltadas à permanência no mercado de trabalho. Esta pesquisa preenche uma lacuna nos estudos organizacionais com uma abordagem psicopolítica da (des)mobilização dos trabalhadores em processos de privatização.

Palavras-chave: Consciência política. Participação. Privatização. Estudos organizacionais. Administração pública.

\section{Consciencia política y predisposición a la participación de los trabajadores de una empresa de saneamiento en acciones colectivas contra la privatización en el sudeste de Brasil}

\section{Resumen}

Este artículo analiza cómo la conciencia política de los empleados de una empresa de saneamiento en Brasil genera una predisposición de estos trabajadores a favor o en contra del movimiento sindical de privatización de la empresa. Su objetivo es comprender los aspectos psicopolíticos de la participación de los trabajadores en acciones colectivas contra la privatización llevadas a cabo por una organización sindical. La investigación se basa en estudios de psicología política y utiliza el modelo analítico de conciencia política para comprender la participación en acciones colectivas (Sandoval, 2001; Sandoval \& Silva, 2016). Los datos se obtuvieron a través de un cuestionario en línea en el sitio web del sindicato, respondido por 87 trabajadores de diferentes categorías profesionales, de un total de 1.400 empleados de la empresa, y, sometido a análisis de contenido. Los resultados revelan conciencias políticas desprovistas de compromiso colectivo, cuyas configuraciones, según las categorías profesionales son: trabajador devotoasistente operativo; trabajador competitivo- asistente administrativo; trabajador difuso-técnicos de saneamiento y trabajador experto- analista de saneamiento. Se concluye que predomina el sentimiento de oposición a la privatización de la empresa, pero sin la participación de los trabajadores en acciones colectivas contra la privatización, que optan por acciones individuales dirigidas a la permanencia en el mercado laboral. Esta investigación llena un vacío en los estudios organizacionales con un enfoque psicopolítico de la (des) movilización de los trabajadores en los procesos de privatización.

Palabras clave: Conciencia política. Participación. Privatización. Estudios organizacionales. Administración pública. 


\section{INTRODUCTION}

An (inter)national literature review about the impacts of privatization on work revealed that few studies address the psychosocial aspects and discuss the political consciousness and the participation of workers in collective actions of the union against the privatization. This article analyzes how the political consciousness of the employees of a sanitation company, in Brazil, generates a predisposition of these workers for or against the anti-privatization union movement of the company. The study aimed to understand the psychopolitical aspects of workers' participation in collective anti-privatization actions conducted by a union organization. The company was cited by the governor of the State of Espírito Santo - Paulo Hartung, of the Brazilian Democratic Movement (MDB) -, in 2016, as one of those to be privatized, a possibility that later was discarded by the state attorney general.

This study was based on qualitative research (Goldenberg, 2004), and supported by quantitative data, adopting the analytical model of political consciousness (Sandoval, 2001; Sandoval \& Silva, 2016). Participation is a process in which two or more parties influence decision-making (Pateman, 1992); it means "being part of or taking part" (Bordenave, 2013, p. 22). According to Sandoval (2001), the individual's decision for an individual or collective action comes from his political consciousness in different contexts. Based on contemporary reflections on society, the model contributes to understanding the political consciousness of workers and the (de)mobilization with the union against the privatization of the company.

The article is structured in 4 sections, in addition to this introduction: a) the first section describes the theoretical framework, supporting the study; b) the second exposes the research methodology; $c$ ) the third one presents the results; and d) the fourth section makes the final considerations.

\section{UNIONS IN A CONTEXT OF PRIVATIZATION}

Privatization on an international level has expanded since the 1970s, led by Margaret Thatcher (England) and Ronald Reagan (United States of America [USA]). In Brazil, privatization was intensified in the 1990s, under the government of Fernando Henrique Cardoso (FHC), of the Brazilian Social Democracy Party (PSDB), and was resumed with intensity in the governments of Michel Temer, of the MDB, in 2016, and of Jair Bolsonaro, of the Social Liberal Party (PSL), in 2018. In all these cases, the adoption of a neoliberal policy that defends the minimum state is observed, although they have promoted privatizations in different economic-social contexts.

To understand the context of unions in the face of privatization, it is necessary to assimilate the State as an outlining agent of political-economic decisions, increasingly influenced by transnational private capital, which progressively dictates the precepts and forms of government management. Labor relations in public services are altered, thus, competence and state efficiency are questioned and privatization is proposed as a solution. The consequences of privatization for universal social rights, highlights lamamoto (2007), are adverse, as they establish selective criteria. Santos (2000) points out that such instrumentalization unties politics and society and Rosa $(2006$, p. 134) highlights that politics are aimed at "realizing the specific interests of economic requirements, those of its rationality, in the privatization process, to the detriment of the political - the collective interests of workers, the common good-". Dalla Corte and Portanova (2015) cite that these distortions are more latent in water supply services, as they treat it with an economic rationale that overlaps its essentiality for the dynamics of human life which, in addition to its essential value, is essential to the implementation of all other social policies.

In 1996, in Europe, a privatization observatory was created by the British unions, arising from the work carried out by the Public Services International Research Unit (1996), in the face of the threat of the weakening of the unions foreseen in the objectives of the Washington Consensus. The objective was to create panoramas and local and global strategies to help the fight against privatization, based on the claim of several unions.

According to Palassi (2006), there are similarities in the post-privatization impacts on workers abroad. Unions are marginalized and companies adopt practices that increase workers' indifference, reducing their union participation, such as professional training, sector representation lobby, legal advice, direct communication, advantageous remuneration systems linked to productivity, 
more egalitarian relationships between managers and workers, techniques to increase commitment and identification with the organization. With due regard for the differences between countries and their specificities in privatization processes, every country suffered psychosocial impacts after these processes. In these countries, fear, insecurity, anxiety, and constant tension were common feelings among workers. These impacts were also seen in Brazil.

The impacts of privatization on labor relations and conditions can be summarized as: a) low salaries; b) deterioration of contractual working conditions; c) devaluation of civil servant status; d) loss of autonomy and identification with the work and organization; e) denial of participation in organizational decisions; f) strong pressure on workers; g) increased competition at work; and h) unions focused on salary demands (Flecker, Schultheis \& Vogel, 2016). The loss of identification with the profession, professional experience, and relationships with colleagues who shared thoughts, ideas, and values related to work generates feelings of frustration (Terra, 2008). The main consequence of privatization for workers is the decrease in jobs, although there is an increase in salaries in some sectors where one worker starts to occupy the jobs of others, exercising various functions (Azmat, Manning \& Van Reenen, 2012).

The logic of privatization and its discourse of greater efficiency at work, without worrying about subjective issues and psychosocial effects on workers' lives, such as insecurity and fear, force higher productivity in exchange for staying in employment (Seršić \& Trkulja, 2009). The exhausting experience causes coping strategies against the constant threat of dismissal from work, questioning their group social insertions in the organization (Palassi \& Silva, 2014). To try to solve the problem, they adopt individual or collective actions, which can be analyzed based on the concept of political consciousness of the analytical model of Sandoval and Silva (2016), described below.

\section{ANALYTICAL MODEL OF POLITICAL CONSCIOUSNESS}

The analytical model of political consciousness for understanding participation in collective actions by Sandoval (2001) is inspired by Touraine's (1966) concept of worker consciousness. Three basic dimensions underpin the construction of Touraine (1966): a) identity (based on class awareness); b) opposition (the individual's perception of his group and groups other than his own); and c) totality (the individual's perception of the social totality, that is, the distribution of goods, domination, as well as its functioning and dynamics). To these dimensions Sandoval (2001) added one more: the predisposition for intervention.

Political consciousness is a set of psychological social dimensions that interrelate meanings and information, making the individual orient and make decisions that represent the best course of action within specific contexts (Sandoval, 2001). Silva (2001, p. 82) points out that "for Sandoval [,] political consciousness is formed by identity aspects (social identity in Tajfel's perspective), by the culture constructed socially and expressed in society". Political consciousness is constituted by the interaction between objectivity and subjectivity within the social process. This process occurs "by a set of beliefs internalized by the individual and by the politicized perception of the social context in which the subject is located (collective identity in Melucci's perspective)" (Silva, 2001, p. 82). Thus, "political consciousness refers to the politicization of the subject, to the subject's politicized actions and, ultimately, to the conscious development of his political character" (Sandoval \& Silva, 2016, p. 34).

However, the identity aspects are insufficient to explain this model. There is an objective aspect, the critical capacity acquired by the individual with his group experiences and the opportunity to temporarily and partially break with some mechanisms of social control, that decrease his chances of developing analytical abstraction (Sandoval, 1989 as cited in Silva, 2001). The model makes it possible to understand the aspects that lead the individual to act individually or collectively, which occur through the combination and articulation of the different dimensions of understanding the phenomenon of political engagement. The model articulates micro and macrosocial aspects, in the psychological perspective of identity construction to understand the dynamics of processes of collective interactions. It is a non-linear model that articulates a set of 7 psychosociological dimensions, enabling different configurations of the consciousness of individuals in a continuous dialectical process of tensions experienced daily (Sandoval \& Silva, 2016). This article adopts the reformulated version of the model, proposed by Sandoval and Silva (2016), as shown in Figure 1, to expand its use. 
Figure 1

Analytical model of political consciousness

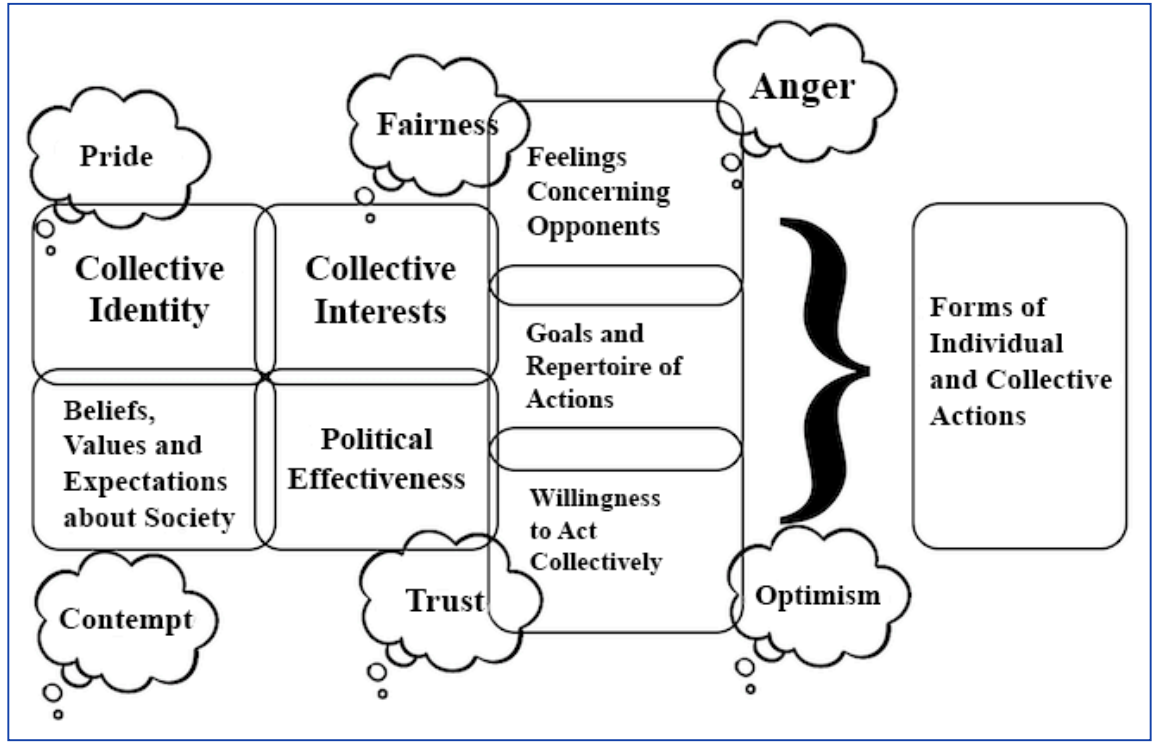

Source: Sandoval and Silva (2016, p. 48).

Collective identity refers to feelings of psychological identification of interests, belonging to a group or social categories, and solidarity with the collective actor. Sandoval (2001) uses the following authors to describe this dimension: Hogg and Abrams (1990), Jenkis (1996), Melucci (1996), Tajfel (1984), and Gamson (1992). According to Ansara (2008, p. 48), "people start to share common interests, which lead them to collective demands, assigning value to group goals and social change as a personal and collective benefit". The feeling of social cohesion makes people instrumentalize themselvess to achieve the desired changes. "Collective Identity means that moment when the individual prioritizes to focus his loyalty and solidarity to a specific social category" (Sandoval \& Silva, 2016, p. 39). With the reformulation of the model integrating emotional feelings, the impact of them on sociability among people stands out, as they influence the desire to (un)group or (un)aggregate with other people or groups.

Beliefs, values, and expectations about society refer to the beliefs, values, and expectations that a person builds about his society. Such representations develop the ideological notions of political consciousness in the individual's worldview. Sandoval (2001), supported by Heller (1972), points out that this dimension is linked to the spontaneity of everyday life, promoting "a conducive condition to the alienation and the subject's self-indulgence due to its non-rationality of daily practices and segmentation to which they are subordinate" (Sandoval \& Silva, 2016, p. 39). To break this non-reflective continuity of the subject, there must be an opportunity to question everyday actions. This dimension considers that emotional feelings affect the consciousness-raising process, influencing the selective retention in the memory of events, experiences, and people from the past, gaining meanings by emotions, as it changes the consciousness-raising process through new meanings given by emotion.

Collective interests refer to common interests shared by the group. Sandoval and Silva (2016) discuss the contrast in the relationship between "my group of belonging" and the "group of others", using Tajfel $(1982,1983)$ and Dominic and Hogg (1998), who established the following requirements for collective participation: a) the feeling of belonging to a group; b) the identification of interests contrary to the maintenance of this group; and c) the identification of groups that have interests rejected by the group they belong to. In Sandoval's (2001) model, Ansara (2008) points out that this dimension has a key role in political consciousness, as it leads to collective action. Emotional feelings impact the individual's willingness to act individually or collectively, partly as a consequence of the emotional meanings previously attributed to events, content, or people. It is in this dimension that the individual's engagement predisposition in the emotional context is manifested, given the notion of a visible opponent and the risk to the maintenance of the group of belonging. 
Political effectiveness refers to the person's feelings about his or her ability to intervene in a political situation. Based on Hewstone (1989), Sandoval (2001) identifies in the attribution theory 3 locus of interpretation of causality in which individuals are based: a) events that are the result of transcendental forces, generating conformation and submission; b) events that are the result of the individual himself, generating isolation and self-punishment; and c) events that are the result of other individuals or groups. This latter location is attributed to people who believe that their actions, individually or in groups, generate changes. For Reck (2005), these convictions that the events are the result of other individuals or groups can lead the subject to a critical view of reality, taking responsibility correctly, organizing themselves to change the social situation, becoming a social actor changing themselves, and the circumstances. "Emotional feelings" attribute significance and relevance to people and the individual's past experiences, allowing the analysis of a contradictory context of their reality, rescuing in their memory elements that assist in the qualitative transformation process of the consciousness to effectively confront similar situations in the present or the future (Sandoval \& Silva, 2016).

Feelings concerning opponents refer to the rupture of the balance between the reciprocal relations that the individual observes in a social arrangement between the actors. Sandoval (2001) relies on Moore (1978) when saying that social justice is the demonstration of reciprocal feelings between obligations and rewards. If this balance is destabilized against the individual, he understands the rupture of these relationships as unfair. According to Ansara (2008), there are groups, individuals, institutions, and government structures that are responsible for the situation of injustice. The recognition of this situation makes people or movements believe that their collective actions represent the possibility of social change. In the model reformulation, Sandoval and Silva (2016) claim that Sandoval (2001) eliminated the feelings of injustice by understanding that such feelings are part of the set of emotional feelings that can be present in any of the elements of consciousness. These contents are elaborated by each individual as they add meanings based on the emotional component brought by the emotional feelings that each person accumulates from their past experiences.

Goals and repertoires of actions associate the objectives and proposals of the social movement and its leadership with the individual's material and symbolic interests. This and the next dimension are more instrumental. They consist in the degree of alignment that those involved perceive the social movement's objectives and action strategies regarding their feelings of injustice and political effectiveness at a given time. Ansara (2008) highlights that, for social transformation to occur, it is necessary to establish action goals that can evoke collective action, so that, in the process of political participation, individuals become aware of their past, their social and political reality and build a political memory that empowers and mobilizes them to participate in political struggles.

Willingness to act collectively is the individual's inclination to take a set of collective actions to restore the injustices committed against him. Based on Klandermans (1992), Sandoval (2001) makes this description. Based on Olson (1965), Sandoval (2005) says that it is an individual analysis of the decision to participate in social movements, which occurs through informed and significant choices of the movement's organizational capacity to implement the proposed collective actions, while assessing costs and benefits.

Faced with the need to integrate the role of emotions in the process of raising people's consciousness, Sandoval (2005) reformulated his model, assuming that emotions have a key role in the formation of political consciousness (Sandoval \& Silva, 2016). For the authors, emotions emerge from the individuals' experiences marking their memory, provoking emotional feelings, mapping their past experiences, which will be remembered when the individual rescues his memory, influencing the consciousness-raising process (Turner, 2005 as cited in Sandoval \& Silva, 2016, p. 46).

Sandoval and Silva (2016) incorporated emotions into the model, in an integrated way, that is, without specifying emotions for each dimension, although illustrations can be made. The dimension of the feelings of justice and injustice that existed in the $\mathbf{2 0 0 1}$ model was eliminated, as these feelings are part of the set of feelings that can appear in the other dimensions, bringing additional meanings to their content. They added the dimension of collective interests inherent to forms of social arrangement, solidarity actions, and common interests shared by the group. And they changed the title of the dimension "goals and actions of the social movement" to "goals and repertoires of actions". This model provides a consistent theoretical contribution to the analysis of the political consciousness of the workers of the researched company, following the methodology presented below. 


\section{METHODOLOGY}

The research field is a sanitation company in southeastern Brazil. The information for this study would be obtained from its employees in an anonymous questionnaire, sent via e-mail by the human resources sector. However, as there was no authorization for the application of this research, it was carried out with the support of the union that represents the category.

The questionnaire for this research was based on the questionnaire adopted by Palassi (1998), in the 1990s, and on the dimensions of the political consciousness model of Sandoval (2001) and Sandoval and Silva (2016). With disclosure on the union's channels (website, Facebook, and WhatsApp), it was possible to carry out the research. For greater access by the researched public, an online Google platform - Google Forms - was used.

In the beginning, the intente was to reach all professional categories of the company, that is, operational assistants, administrative assistants, technicians, analysts, and managers, but only one manager was identified; therefore, that category was excluded. The company had about 1,400 employees and the answers are only from those who were active. The research uses qualitative methods, supported by quantitative data, allowing a better crossing of the conclusions. The data obtained do not result from a particular situation and are reliable (Goldenberg, 2004). The elaboration of the questions started from blocks guided by the 7 dimensions proposed by Sandoval and Silva (2016).

The online questionnaire was available on the union's website from July 13 to August 24, 2017. 90 responses were obtained, only 87 of which were validated for the following reasons: a) one was duplicated; b) another was a retired employee; and c) the third did not belong to the company's staff. The questions were semi-structured; closed responses were translated into graphs and open responses were submitted to content analysis a priori, as proposed by Bardin (2004), using the dimensions of political consciousness (Sandoval \& Silva, 2016) as macro-categories of analysis. Based on this content analysis, different types of political consciousness of the professional categories were identified, whose main mark is in their name.

The sample is non-probabilistic and reached, among the professional categories: a) 14 operational assistants; b) 14 administrative assistants; c) 34 technicians; and d) 24 analysts. Thus, the categories are represented in a very limited and restricted analysis, which does not prevent it from undergoing content analysis based on the theoretical framework of this study. Therefore, this research is limited to addressing the political consciousness of those who answered the questionnaire and the results cannot be generalized to the entire population of the company, as they lack statistical criteria. Thus, it does not result in a representative sample, as not all elements of the population have the same chance of being chosen (Freitas, Oliveira, Saccol \& Moscarola, 2000) and the rigor of the research in the quantitative sense cannot be guaranteed, due to limitations of validity. This study is limited to the use of quantitative data to assist in understanding the qualitative dimensions of the research.

\section{COMMON ASPECTS AMONG THE PROFESSIONAL CATEGORIES}

Research participants, in the 4 professional categories, present similar traits in several aspects. Regarding age, $61 \%$ are between 30 and 40 years old, $25 \%$ are between 40 and 65 years old, and $9 \%$ between 24 and 30 years old, while $5 \%$ did not inform their ages. The workers are predominantly someone who has not yet reached half of their professional career, based on experiences in the Brazilian political context of the last 2 decades, which influence the construction of his or her political consciousness.

Regarding working time in the company, there are 2 groups, one from 3 to 13 years old, corresponding to $81 \%$ of the survey, and another from 27 to 41 years old, corresponding to $16 \%$. It is noted that a significant portion of the workers surveyed has a professional relationship with the company for approximately a decade. As for education, $16 \%$ have a high school education, $16 \%$ have incomplete higher education, $30 \%$ have complete higher education and $35 \%$ have postgraduate degrees. Thus verifying a high level of academic education.

Most workers are young, well-educated, have professional ambitions, are aware of the social importance of sanitation, and see privatization as a threat to their jobs and the good provision of this service. 


\section{THE POLITICAL CONSCIOUSNESS SETTINGS OF THE PROFESSIONAL CATEGORIES}

Research participants, in the 4 professional categories, have similar traits in several aspects, such as: a) age; b) education; and c) working time in the company. They are political consciousness devoid of collective engagement, whose settings, according to professional categories, are: a) devout worker - operational assistant; b) competitive worker - administrative assistant; c) diffuse worker - sanitation technicians; and d) expert worker - sanitation analyst.

The operational assistants, devout workers, have a political consciousness susceptible to union mobilization. A collective identity is perceived as it involves a sense of belonging and a desire to fight privatization. They form a group that, for the most part, corresponds to $64 \%$ of them and has a certain homogeneity, proven through their predominant characteristics: a 38-year-old professional that is 7 years in the company, and in the core activity of the organization. They show the best organizational climate and the lowest appreciation of salary recognition. All are affiliated with the union and against privatization. It is the least educated category, however, $43 \%$ have higher education. Political effectiveness reached the highest index in the survey. However, the workers themselves recognize little collective engagement, waiting for this mobilization to come from the union.

The administrative assistants, competitive workers, have a political consciousness less predisposed to union mobilization, with more individualized than collective characteristics, observable in the contrasts between professionalism and union values. They have an expressive homogeneity, $86 \%$ are within the average of 34 years of age and are 8 years in the company. With a high level of education, more than $80 \%$ have a degree, it was the category that, only below the operational ones, demonstrated the most recognition for the political effectiveness of the union. However, this effectiveness is limited to union agreements, as, in terms of privatization, individual actions to improve professional qualification to maintain employment or receive external opportunities are sought. The perception of appreciation is recognized by the benefits acquired, such as health insurance and competitive salaries. This category did not demonstrate a willingness to act collectively, as their repertoires of actions did not indicate collective mobilization, the majority being of a personal nature or with a tendency to avoid confrontation.

The technicians, diffuse workers, are the most representative and correspond to $39 \%$ of the individuals surveyed. Its homogeneous group is equivalent to $80 \%$ of the category, with the average characteristic being a 33 -year-old worker with 8 years in the company. Similar to administrative assistants, more than $80 \%$ have higher education and recognize the company's appreciation through health insurance and competitive salaries. The political consciousness of this category is located in an intermediate zone between volubility and predisposition to collective actions. These oscillations appear in the dispersed collective identity, as there are varied perceptions about the company and the union, ranging from feelings of passion, pride, and respect to embarrassment, frustration, and abandonment, on one hand, and on the other, representative, combative and essential, but also irrelevant, absent and based on outdated ideologies. In the beliefs and values, approaching the operational ones, balances between professionalism, companionship, and unity are identified. Political effectiveness is almost symmetrically divided between those who believe in collective mobilization and those who do not believe that the union can alter the privatization process. It can be seen, as in the previous professional categories, that the speeches are devoid of actions aimed at collective engagement.

The analysts, expert workers, make up $28 \%$ of the survey. It is the second-largest quantitative representation on the research and the most homogeneous category, corresponding to $96 \%$ of the professional category. The average trait in this category is a 36-year-old worker with 8 years of work. Like the operational assistants, they are unanimously against privatization. As the category is formed only by graduates, there is a greater number of postgraduates (75\%), followed by administrative assistants (37\%) and, finally, technicians (26\%). With characteristics similar to the high school administrative category, it has an accentuated professionalism in relation to the other variables, such as union and companionship. Of all respondents, this category has the best perception of recognition by the company, attributing the main reward factors to the career plan and salary. It is understood, therefore, the presence of the adversary called privatization, since this was the category with the highest negative index concerning the maintenance of benefits in case the privatization is carried out. Below the operational assistants, analysts are the second category to adopt, as an action strategy, union membership. The political consciousness of this category comes close to that of operational assistants regarding the position against privatization. These workers see the union as the fundamental entity in this confrontation, as they recognize that actions, to become collective, need an integrated movement, articulator, and activator of social mobilizations. 


\section{DIFFERENCES AND SIMILARITIES IN THE DIMENSIONS OF THE POLITICAL CONSCIOUSNESS OF THE PROFESSIONAL CATEGORIES}

The collective identity promotes the feeling of belonging to groups. two collective actors are the focus of common ideals in the identification process of the worker: a) the company; and b) the union. The first guarantees livelihood and professional achievement and the second, the defense of the guarantees of the first. The collective identity is expressed in different ways as to the intensity between the categories. If for the operational assistant the feeling that reveals social cohesion is found in security and protection, for the administrative assistants, technicians and analysts this cohesion loses ground to the achievements, learning, and professional achievement, showing a less collective position. This indicates greater loyalty to the company and the union in the operational assistants' category, while the other categories identify more with the company, the focus of its achievements, but perceive the union as a legitimate representation, however, without reaching personal instrumentalization for a collective identity.

In the beliefs, values, and expectations about society, it was observed that the discussion of privatization causes the rupture of daily life and promotes the confrontation of these relationships. Operational assistants and analysts unanimously do not believe in privatization as a solution to sanitation problems. Among all categories, only 3 arguments were in favor of privatization, related to inefficiency and the outdated management model provided by the public sector. Another 4 did not know how to answer, but showed personal interests in their indeterminacy and did not distinguish a safe management model for the sector. The contrary arguments were based on the competence of the service provided by the State and the risks of dismissal. It is inferred a direct relationship between the values of union and companionship, most mentioned in these 2 categories, as a propensity for collective action. In contrast, the administrative assistants and technicians, when showing the feeling of individualism and omitting the consideration of the status of working in the company, demonstrate tendencies for individual actions. The emphasis that workers place on professionalism is highlighted: $64 \%$ of operational assistants, $86 \%$ of administrative assistants, $65 \%$ of technicians, and $83 \%$ of analysts - a characteristic in line with professional specialization. To understand the meaning of work in the company, we seek to interpret the emotional feelings of the worker in the development of his ideological notions. It was observed in the questionnaire data the predominance of the feeling of security and exalting expressions (pride, passion for what you do, giving your life for the company, specialization in your career), but also disheartening foreshadows (outsourcing in progress, it was once safe ... today we have only uncertainty), spread across the 4 categories. However, the similarities disappear in the unanimous opponents of privatization when it comes to uncertainties and frustrations regarding work in the company. Operational assistants and analysts occupy the extremes, with $57 \%$ and $12 \%$, respectively. It is curious to note that these 2 categories are the ones that most expect to develop their entire professional career in the company, but with such a contrasting feeling of professional insecurity. It is perceived in the most prominent values in the working relationship with colleagues, in the meaning of work in the company and in expectations about the company that the ideological notion of political consciousness of technicians and administrative assistants translates into an individualized action, while the operational assistants and analysts reinterpret these threats through collective values.

In the collective interests, it was found that the maintenance of the public company is shared by the majority of workers in the 4 categories, as highlighted in the previous dimension. It was identified that the threat and the visible adversary against collective interests are privatization and the political interest of the state government. Analysts, followed by operational assistants, are more homogeneous in identifying the visible adversary: the government's interest in the 3 administrative spheres. Administrative assistants and technicians pointed out, albeit minimally, that privatization is a way to attract investment and increase sanitation coverage. None of the 4 categories cites the alarming reports of market institutions on the water, economic and anti-corruption crises in the public sector. This dimension assumes a decisive role in political consciousness, as it predisposes the worker to participate in collective actions, having the union as the identity group responsible for the defense and maintenance of the category. According to workers, there are more viable alternatives for investments and economic development of the company, beyond privatization. There is unanimity regarding these alternatives, such as: a) preventing political interference; b) improve public management; and c) promoting career leadership in the company.

In political effectiveness is the union, an organization that represents the legitimate category to intervene. One of the goals was to understand how workers evaluate the union's performance in the context of privatization. Responses emphasizing its importance and capacity to mobilize within the category, being an essential actor in the anti-privatization movement prevailed. However, this feeling is not unanimous, as there are opinions that vary from the primary role in the mobilization of collective 
anti-privatization actions to an inert role or one with very weak performance, not very incisive, divergent, alienated and without political effectiveness. Technicians are those who least attribute political effectiveness to the union, presenting the highest index of disbelief in the strength of the union's intervention and the lowest index of expansion of the privatization privatization debate with society, and those who least organize themselves to change the social situation. However, there is a margin of opportunity for the union, as it is the category that most demands better communication with workers. On the other hand, analysts occupy the lead in the claims to expand the privatization debate with society and to improve the union's communication with the company. Operational assistants, who have a greater collective union identity, are second only to technicians regarding low trust in the union. They also take second place, demanding better communication with workers. A frustrating experience with the union is perceived, as they are the closest and the most disappointed. The administrative assistants are the ones that reveal the best index of belief in the union, a curious fact, given the already analyzed category preferences for individualized actions. Unlike the analysts, it is the category that signals the least improvement in the union's communication with the company and is still the one that least signals that the union should improve its communication with the workers. It seems that this category is the least involved in union experiences, as it has low union collective identity, high individual value, and few frustrations with the union, having knowledge of union representation, however, showing itself distant from the collective actions promoted by the union.

In terms of feelings towards opponents, the category that stands out is that of the operational assistants, where the lowest level of recognition by the company for its performance is found. On the opposite side are the analysts, with the best recognition indicators of the company. Likewise, the perception of dedication and commitment of workers is higher in the categories of analysts and administrative assistants, while in the operational assistants, the lowest index among the categories was found, despite all identifying themselves at high levels of commitment. This feeling is confirmed when analyzing the responses to when they were asked about the rewards that the company provides them with: for analysts, the career plan and competitive salary rates are above $70 \%$; for administrative assistants, the biggest indicator is in the health plan, reaching $57 \%$; the same characteristic of the technicians, however, these are not more than $35 \%$. The biggest reward indicator for operational assistants is in the good organizational climate and managers who promote a pleasant internal environment (43\% of the responses), compared with analysts, this demand is $16 \%$. There is, in this dimension, the greatest discrepancy between categories. Analysts, followed by administrative assistants, have the best perceptions of balance in the relationships. The operational assistants, followed by the technicians, reveal the worst perceptions of social justice in the arrangement of obligations and rewards in the workplace.

In goals and repertoires of actions was identified the degree of alignment between workers and the union regarding the objectives and action strategies, feelings of injustice, and political effectiveness. The workers, in general, in the 4 categories, consider that the main actors in the privatization of the company are the state government and the corporate lobby. When considering the union as an actor with a low potential for political effectiveness to reverse their feelings of injustice in the face of privatization, all professional categories decide, with different intensities, to improve themselves for the job market. Technicians are the only category that adopts this strategy as the main option. Analysts and operational assistants prefer, mainly, to improve their performance in the company. And administrative assistants tie in prioritizing strategies with internal and external focus. Regarding the positive and negative factors of participating in the union's actions, among the positive ones, the workers mention: a) strengthening of the category; b) consciousness-raising and space for construction; c) positive changes for the worker; d) more information; e) support in the struggle to maintain benefits, etc. When questioned the negative reasons for not participating in these actions, they mention persecution, distrust, and intolerance within the company, alienation, etc.

Analysts (43\%) and operational assistants (28\%) are more receptive to participation in union actions. Technicians (17\%), followed by administrative assistants ( $21 \%)$, are the most skeptical. When comparing the influence of the company and the union in the context of privatization, it is noted that the company is seen as much more influential than the union, which justifies the concern of workers to participate in visible actions of the union, fearing reprisal from the company. Workers fear more the company leadership than have confidence in the union leadership.

In the willingness to act collectively, it was found that the majority of workers are against privatization, however, they recognize that they do not take actions that would allow a change of scenery and are only waiting to see what will happen. Those who favored privatization consider this possibility, seeking qualification and preparing for the moment when it comes 
to fruition. The goals and actions that the union must implement during the privatization process of the company seem to be explicit in the questionnaire responses, however, the engagement of workers in the defense of the cause is absent. There is a gap between the discourse and the mobilizing practice of collective engagement in the responses to the questionnaire. In this dimension, the worker makes an objective analysis to decide whether or not to participate in collective actions against privatization. Operational assistants are those who most identify the union's objectives and strategies as in line with those of workers, both in the collective and individual sense of interest. However, the administrative assistants have the lowest indicators of alignment of collective actions between union and workers. A high level of bias in the categories was perceived, indicating the workers' imprecision regarding the union's actions and strategies. This lack of definition is more pronounced among analysts and administrative assistants. The technicians, although also showing themselves as biased, constitute the only category that cites the union's objectives and strategies in disagreement with the collective of workers. However, projecting the individual interest of the worker, all categories register disagreement with the union. The willingness to act collectively is due to the individual and objective analysis that the worker makes of his information and meanings about the context and the political situation of the social actors. It is noted that there is no set of objectives and strategies defined in the political consciousness of workers to feel determined to organize themselves, aiming to restore the injustices committed against them. Workers are not inclined to take collective actions with the union in the fight against privatization.

The results of the survey reveal the psychopolitical aspects that justify the preference for individual action aimed at maintaining employment or re-placement in the job market, instead of the collective anti-privatization action of the union. It is observed that these workers are aware of the risks that privatization presents, mentioned in the literature review, generating low predisposition to participation, due to the feeling of lack of political effectiveness and unwillingness to act collectively, as the union's goals and repertoires of anti-privatization collective actions make them believe that they are insufficient to fight the main privatization actors, as adherence to collective anti-privatization actions would make them visible and more vulnerable to dismissal if privatization takes place.

\section{FINAL CONSIDERATIONS}

Through the model of political consciousness (Sandoval, 2001; Sandoval \& Silva, 2016), from the responses to the questionnaire, a parallel was drawn between the configurations that permeate the positions and engagements of workers, considering the company and the union. Workers in the four professional categories are opposed to the privatization of the company. It is concluded that the collective anti-privatization actions are used in a diminished way, due to the belief that their labor guarantees will be unprotected by the exposure that this action produces, seeming to them to be more effective, in this case, the individual action aimed at meritocracy, that is, less confrontational actions and expository risks against privatization and which are aimed at remaining in the company or relocating outside it.

The state government (majority shareholder), followed by the business lobby, are the main influencers of this prediction of helplessness, there is no correlation between economic or water crisis and privatization (no worker pointed this out), and the fight against corruption is seen as a small argument (just an indication). Among the various questions, it appears that the professional categories of the company have a high level of academic education and increased awareness of the social role of sanitation for the population.

There is a strong sense of belonging to the company, characterizing, and reinforcing the collective identity. However, workers are not involved in sanitation policies, as there are no engagement practices in their reports. They express a certain repudiation of the union's political-party position, as they understand that such bias is not politically effective. However, they recognize the union's legitimacy and its fundamental role in the fight against privatization, however, little participation by society was seen due to the union's inability to involve it in the discussion.

Although there were more than $85 \%$ of affiliates in the responses to the questionnaire, there was no unanimity in the recognition of the representativeness of this union. A considerable part ( $1 / 3$ of those surveyed) questioned the union's bias in the treatment of certain professional categories, its succumbing when pressed by the company and its ideological positions, often considered outdated or divergent from their own, making it difficult to build a sense of collective identity in relation to 
the union. The union's lack of political effectiveness makes it possible to understand the reason for the low involvement of employees in collective anti-privatization actions. However, when it comes to collective work agreements aimed at meeting the interests of all professional categories in the domestic scenario, the union can be counted on as an entity with repertoires of actions and engagement, in addition to collective mobilization strength, recognizing and valuing their actions.

This article fills a gap in organizational studies, people management, work relationships, and the psychosocial impacts of privatization at work, allowing the understanding of the (de)mobilization in the union's anti-privatization collective actions, also serving as a diagnosis for the investigated union. Finally, it appears that the model adopted makes it possible to understand political consciousness, as it covers subjective and objective fields of the psychosocial structure, through the dimensions of consciousness aimed at both internal perspectives (collective identity; beliefs, values, societal expectations; collective interests) and external (political effectiveness, feelings regarding opponents, willingness to act collectively, goals and repertoires of actions), articulating them simultaneously to understand decision making through individual or collective action. Although the model reformulated in 2016 allows the analysis of political consciousness emerging from the group by the group itself, in a perspective guided by self-assessment, without depending on the comparison with an opponent who is always outside the investigated group, it appears that most of the studies that use the model, including this research, adopt it based on the existence of a threat, a discordant actor and the distinction between my group and the other's group, demarcating antagonistic actors. Therefore, it is recommended that in future work with unions the researchers use the political consciousness model in a self-analysis perspective, to identify opponents within the union and in the professional categories that are part of it, aiming at strengthening the collective identity of the union with its affiliates and the willingness to act collectively in defining goals and repertoires of actions in defense of their interests. 


\section{REFERENCES}

Ansara, S. (2008). Memória política: construindo um novo referencial teórico na psicologia política. Psicologia Política, 8(15), 31-56.

Azmat, G., Manning, A., \& Van Reenen, J. (2012). Privatization and the decline of Labour'Share: international evidence from network industries. Economica, 79, 470-492.

Bardin, L. (2004). Análise de conteúdo (3a ed.). Lisboa, Portugal: Ed. 70.

Bordenave, J. E. D. (2013). O que é participação (Coleção Primeiros Passos). São Paulo, SP: Brasiliense.

Dalla Corte, T., \& Portanova, R. S. (2015). Movimento por justiça ambiental e sustentabilidade: fundamentos para a governança da água. Culturas Jurídicas, 2(3), 74-99.

Dominic, A., \& Hoog, M. A. (1998). Social identifications: a social psychology of group relations and group processes. Londres, UK: Roudtledge.

Flecker, J., Schultheis, F., \& Vogel, B. (2016). A "problem of fairness" in the making: the transformation of public services from the perspective of postal workers. British Journal of Industrial Relations, 54(4), 768-789.

Freitas, H., Oliveira, M., Saccol, A. Z., \& Moscarola, J. (2000). O método de pesquisa survey. Revista de Administração, 35(3), 105-112.

Gamson, W. A. (1962). Talking politics. Cambridge, UK: Cambridge University Press.

Goldenberg, M. (2004). A arte de pesquisar (8 ed.). Rio de Janeiro, RJ: Record.

Heller, A. (1972). O cotidiano e a história. Rio de Janeiro, RJ: Paz e Terra, 1972.

Hewstone, M. (1989). Causal atributtion: from cognitive processes to collective beliefs. London, UK: Blackwell, 1989.

Hogg, M. A., \& Abrams, D. (1990). Social Motivation, Self-Esteem and Social Identity. In D. Abrams, \& M. A. Hoog (Eds.), Social Identity Theory: Constructive and Critical Advances (pp. 28-47). London, UK: Harvester Wheatsheaf.

lamamoto, M. V. (2007). Serviço social em tempo de capital fetiche: capital financeiro, trabalho e questão social. São Paulo, SP: Cortez.

Jenkis, R. (1996). Social identity. Londres, UK: Roudtledge.

Klandermans, B. (1984). Mobilization and participation: social psychological expantion of resource mobilization theory. American Sociological Review, 49(5), 583-600.

Melucci, A. (1966). Challenging codes. Cambridge, UK: Cambridge University Press.

Moore, B. (1978). Injustiça: a base social da obediência e revolta. São Paulo, SP: Cortez.

Olson, M. (1965). A lógica da ação coletiva. São Paulo, SP: EDUSP.

Palassi, M. P. (1998). Se correr o bicho pega, se ficar o bicho come! O impacto da notícia de municipalização privatizada sobre trabalhadores do setor de saneamento (Master Thesis). Universidade Federal do Espírito Santo, Vitória, ES.

Palassi, M. P. (2006). Os impactos psicossociais do movimento privatizador nos trabalhadores. Psicologia Política, 6(11), 169-196.

Palassi, M. P., \& Silva, A. L. (2014). A dinâmica do significado do trabalho na iminência de uma privatização. Revista de Ciências da Administração, 16(38), 47-62.

Pateman, C. (1992). Participação e teoria democrática. Rio de Janeiro, RJ: Paz e Terra.

Public Services International Research Unit. (1996). Public Services Privatizations Research Unit. London, UK: University of Greenwich.

Reck, J. (2005). A consciência política dos cooperados do MST: o caso do COOPAC-Campo Verde/MS (Doctoral Dissertation). Programa Pós-Graduação em Educação, Faculdade de Educação, Universidade Estadual de Campinas, Campinas, SP.

Rosa, M. I. (2006). Trabalho, subjetividade, política. Psicologia Política, 6(11), 131-138.

Sandoval, S. A. M. (2001). The crisis of the Brazilian labor movement and the emergence of alternative forms of working-class contention in the 1990s. Psicologia Política, 1(1), 173-195.

Sandoval, S. A. M. (2005). Emoções nos movimentos sociais (Trabalho apresentado na mesa-redonda Emoções, Engajamento e Movimentos Sociais). In Anais do 13o Encontro Nacional da Associação Brasileira de Psicologia Social, São Paulo, SP.

Sandoval, S. A. M., \& Silva, A. S. (2016). O modelo de análise da consciência política como contribuição para a psicologia política dos movimentos sociais. In: D. U. Hur, \& F. Lacerda, Jr. (Orgs.), Psicologia, políticas e movimentos sociais (pp. 25-52). Petrópolis, RJ: Vozes.

Santos, M. (2000). Por uma outra globalização: do pensamento único à consciência universal. Rio de Janeiro, RJ: Record.

Seršić, D. M., \& Trkulja, J. (2009). Nesigurnost posla kao predmet istraživanja u psihologiji: teorije, operacionalizacije, nalazi. Društvena Istraživanja: Časopis za Opća Društvena Pitanja, 18(3), 523-545.

Silva, A. S. (2001). Consciência e participação política: uma abordagem psicopolítica. Interações, 6(12), 69-90.

Tajfel, H. (1982). Grupos humanos e categorias sociais: um estudo psicossocial I. Lisboa, Portugal: Livros Horizonte.

Tajfel, H. (1983). Grupos humanos e categorias sociais: um estudo psicossocial II. Lisboa, Portugal: Livros Horizonte.

Tajfel, H. (1984). Grupos humanos e categorias sociais: um estudo psicossocial III. Lisboa, Portugal: Livros Horizonte.

Terra, L. M. (2008). La pérdida del trabajo petrolero: transformaciones laborales, materiales e identitarias. Avá, 12, 95-116.

Touraine, A. (1966). La consciènce ouvriére. Paris, France: PUF. 
Estéfanes Silva Oliveira

ORCID: https://orcid.org/0000-0003-2800-5164

Graduated in Administration from the Federal University of Espírito Santo (UFES). E-mail: estefaness@gmail.com

Márcia Prezotti Palassi

ORCID: https://orcid.org/0000-0002-0751-6777

Doctor of Social Psychology from the Pontifical Catholic University of São Paulo (PUC-SP); Professor of the Administration Department and of the Administration Post-Graduation Program of the Federal University of Espírito Santo (UFES). E-mail: mprezotti@hotmail.com

Ana Paula Paes de Paula

ORCID: https://orcid.org/0000-0001-8035-472X

Doctor of Social Sciences from the State University of Campinas (UNICAMP); Professor of the Administrative Sciences Department and of the Administration Post-Graduation and Research Center of the Federal University of Minas Gerais (CEPEAD/UFMG). E-mail: appp.ufmg@gmail.com 